\title{
Use of Medetomidine for Sedation in the Laboratory Rats (Rattus norvegicus)
}

\author{
K. HAUPTMAN, V. JEKL, JR., Z. KNOTEK
}

Avian and Exotic Animal Clinic, Faculty of Veterinary Medicine, University of Veterinary and Pharmaceutical Sciences Brno

Received June 22, 2003

Accepted November 29, 2003

Abstract

Hauptman K., Jekl V. Jr., Knotek Z.: Use of Medetomidine for Sedation in the Laboratory Rats (Rattus norvegicus). Acta Vet. Brno 2003, 72: 583-591.

Sixty-three rats (Rattus norvegicus) assigned to ten groups of six to seven animals were evaluated for depth and quality of sedation induced by intramuscular medetomidine. The first group received a dose of $50 \mu \mathrm{g} / \mathrm{kg}$ of medetomidine and the dosages in the other groups were 150 $\mu \mathrm{g} / \mathrm{kg}, 200 \mu \mathrm{g} / \mathrm{kg}, 250 \mu \mathrm{g} / \mathrm{kg}, 300 \mu \mathrm{g} / \mathrm{kg}, 350 \mu \mathrm{g} / \mathrm{kg}, 400 \mu \mathrm{g} / \mathrm{kg}, 450 \mu \mathrm{g} / \mathrm{kg}$ and $500 \mu \mathrm{g} / \mathrm{kg}$ respectively. Respiratory rate, peripheral pulse, blood oxygen saturation, and disappearance and recovery of reflexes were evaluated at 5-minute intervals for the period of 60 minutes from the medetomidine injection. Disappearance of the lateral reflex was observed within 15 minutes in the $3^{\text {rd }}$ group and within 10 minutes in the $4^{\text {th }}$ to $10^{\text {th }}$ group. The peak of the sedation of the rat population was located between minute 10 and minute 20. All groups showed a drop in pulse rate, namely by $26 \%$ on average in the $2^{\text {nd }}$ group, by $18 \%$ in the $3^{\text {rd }}$ group, and by over $30 \%$ in groups 4 to 10 . In groups 2 and 4 , the maximum drop in pulse rate in minute 60 compared with minute 5 was by $30 \%$; the drop was by $63 \%$ in group 10 . Statistical evaluation of blood oxygen saturation did not reveal any statistically significant differences between the individual groups. The average blood oxygen saturation was $90.9 \pm 4.34 \%$. Recovery of reflexes after the atipamezole injection was monitored at 1-minute intervals. All reflexes under evaluation were recovered within 5 minutes. Our recommendation regarding rat sedation is to apply medetomidine from 150 to 250 $\mu \mathrm{g} / \mathrm{kg}$. Higher dosages induce a relatively strong respiratory depression.

Rodents, anaesthesia, sedation monitoring

Small mammals represent a specific group of patients in clinical veterinary practice. For reasons of rather difficult patient handling, a number of procedures that are part of the routine checkup of small mammals (e.g. blood sample taking, skin biopsy, X-ray and ultrasonography examinations) require patient sedation. The drugs recommended for sedation of small mammals are the following: acepromazine, diazepam, midazolam, xylazine, ketamine, and tiletamine-zolazepam (Hes s et al. 1984; Flecknell 1991; Mas on 1997; Cantwell 2001). Some of them are designed for special indications e.g. diazepam and midazolam can be used in aggressive and nervous animals thanks to their anxiolytic and anticonvulsive effect and the possibility of antagonization by flumazenil (Clarke 1992). Acepromazine is used, among other things, for its antiemetic and spasmolytic effect (Thurmon et al. 1996). Xylazine is characterized by sedative and myorelaxation effects and a short-time analgesia (Klein and Klide 1989; Lukasik 1999). Ketamine in higher dosages induces perfect immobilization, which may, however, be occasionally associated with undesirable effects, especially convulsions (Hes s et al. 1984). Tiletamine-zolazepam have a relatively fast onset of sedation. Also, the analgesic effect of the combination is milder and irreversible renal damage may occur in some animals (rabbit) (B rammer et al. 1991; Doerning et al. 1992).

To improve the quality of sedation, especially with respect to the induction and recovery speed, the alpha-2-adrenergic agonist medetomidine is used to a relatively great extent $\mathrm{(Hu}$ et al. 1992). The affinity of medetomidine to alpha- 2 receptors is ten times higher than that

Address for correspondence:

Prof. MVDr. Z. Knotek, CSc.

Avian and Exotic Animal Clinic

Unersity of Veterinary and Pharmaceutical Sciences

Palackého 1-3, CZ - 61242 Brno, Czech Republic
Phone: +42054156238

Fax: +420541562381

http://www.vfu.cz/acta-vet/actavet.htm 
of xylazine and the drug can be fully antagonized by atipamezole (Ko et al. 1997). The undesirable effects of medetomidine include cardiopulmonary depression including brachycardia, hypertension, and reduced cardiac output (Muir and Mason 1996). Medetomidine is used in different animal species (Jalanka 1989; Klein and Klide 1989; Jalanka et al. 1990; Flecknell and Liles 1996; Jonson-Delaney 1999; Langan et al. 2000). The dosages recommended for rats range between 30 and $1000 \mu \mathrm{g} / \mathrm{kg}$ (J on s onDelaney, 1999; Cantwell 2001). On the other hand, there is a lack of more detailed information on the course of sedation of rats by medetomidine in a narrower range of dosages. The aim of this study was therefore to identify and propose an optimum dosage of medetomidine for sedation of rats (Rattus norvegicus), i.e. to narrow down the range of dosages commonly quoted in literature.

\section{Materials and Methods}

Animals and their health condition

The trial included 63 rats (Rattus norvegicus) of the Wistar strain, of which 16 were males and 47 females, aged from 10 to 14 months, with weight ranging from 320 to $460 \mathrm{~g}$. The animals were SPF rats screened in order to eliminate pathogens according to FELASA standards. A control clinical examination including checking the fur, the colour of the mucosae, checking the size of submandibular and popliteal lymph nodes by palpation, auscultation of the cardiovascular and respiratory systems, and palpation of the abdominal cavity was performed prior to inclusion in the trial and immediately before sedation. The animals were clinically healthy individuals. They were randomised into 10 groups of 6 to 7 (see Table 1). The rats were not given any food for 4 hours prior to medetomidine injection; water intake remained unrestricted.

Table 1

Experimental animals

\begin{tabular}{|c|c|c|c|c|c|c|}
\hline \multirow[t]{2}{*}{ Group } & \multicolumn{3}{|c|}{$\begin{array}{c}\text { Number } \\
\text { of rats }\end{array}$} & \multirow{2}{*}{$\begin{array}{c}\text { Mean body } \\
\text { weight } \\
\text { (g) }\end{array}$} & \multirow{2}{*}{$\begin{array}{c}\text { Medetomidine } \\
\text { IM } \\
(\mu \mathrm{g} / \mathrm{kg})\end{array}$} & \multirow{2}{*}{$\begin{array}{c}\text { Atipamezole* } \\
\text { IM } \\
(\mu \mathrm{g} / \mathrm{kg})\end{array}$} \\
\hline & Total & Males & Females & & & \\
\hline 1. & 6 & 4 & 2 & $382 \pm 97.5$ & 50 & 25 \\
\hline 2. & 7 & 3 & 4 & $429 \pm 27.9$ & 100 & 50 \\
\hline 3. & 7 & 3 & 4 & $433 \pm 66.3$ & 150 & 75 \\
\hline 4. & 7 & 4 & 3 & $447 \pm 95.7$ & 200 & 100 \\
\hline 5. & 6 & 6 & 0 & $372 \pm 27.9$ & 250 & 125 \\
\hline 6. & 6 & 4 & 2 & $430 \pm 147.4$ & 300 & 150 \\
\hline 7. & 6 & 6 & 0 & $352 \pm 24.0$ & 350 & 175 \\
\hline 8. & 6 & 6 & 0 & $335 \pm 28.1$ & 400 & 200 \\
\hline 9. & 6 & 6 & 0 & $340 \pm 39.5$ & 450 & 225 \\
\hline 10. & 6 & 5 & 1 & $388 \pm 27.9$ & 500 & 250 \\
\hline
\end{tabular}

* atipamezole (Antisedan inj., Pfizer) was injected 60 minutes after medetomidine (Domitor inj., Pfizer)

Sedative and antidote

Medetomidine (Domitor inj., Pfizer) was intramuscularly applied into the left hind leg ( $\mathrm{m}$. semimembranosus et semitendinosus). The patients assigned to the different groups received $50 \mu \mathrm{g} / \mathrm{kg}$ (group 1), $100 \mu \mathrm{g} / \mathrm{kg}$ (group 2 ), $150 \mu \mathrm{g} / \mathrm{kg}$ (group 3), $200 \mu \mathrm{g} / \mathrm{kg}$ (group 4), $250 \mu \mathrm{g} / \mathrm{kg}$ (group 5), $300 \mu \mathrm{g} / \mathrm{kg}$ (group 6.), $350 \mu \mathrm{g} / \mathrm{kg}$ (group 7), 400 $\mu \mathrm{g} / \mathrm{kg}$ (group 8), $450 \mu \mathrm{g} / \mathrm{kg}$ (group 9), $500 \mu \mathrm{g} / \mathrm{kg}$ (group 10) of medetomidine. Sixty minutes after the medetomidine injection, the rats were administered atipamezole into the same muscle region of the right hind leg (Antisedan inj., Pfizer), the dosage being the half of the initial dose of medetomidine. The parameters monitored were the onset of resuming a sternal position spontaneously, recovery of the palpebral reflex, and recovery of surface and depth sensibility.

Reflex and sensibility check

The rats were placed on a thermal pad of $39{ }^{\circ} \mathrm{C}$ during the sedation. The times of resuming a lateral position, of the loss of the palpebral reflex, and of the loss of the surface and depth sensibility were recorded. The lateral position was regarded as resumed when the animal was not able to go back to a sternal position from the lateral position induced by the progressive sedation. The palpebral reflex was evoked by touching the lower eyelid and was 
regarded as present when the animal responded to stimulation by closing the eyelids. Surface tactile sensibility was checked by clamping the skin in the region of the last thoracic vertebra with forceps. Depth sensibility was provoked by clamping the interdigital area of the hind leg with forceps.

Pulse, respiratory rate, and blood oxygen saturation monitoring

After resuming a lateral position spontaneously, a finger clamp of the pulse oximeter (V3301 Pulse oximeter, SurgiVet, USA) was attached to the left front leg of the animal. The probe was located in the a. antebrachialis superficialis, a. radialis superficialis, a. ulnaris, v. cephalica, v. ulnaris area. Pulse rate and respiratory rate values as well as values of blood oxygen saturation $\left(\mathrm{SpO}_{2}\right)$ were recorded at 5-minute intervals for 60 minutes. Respiratory rate in the rats was evaluated by the control of breast movements. For the rats from groups 2 to 10, in whom the lateral reflex disappeared and respiratory rate, pulse rate, and blood oxygen saturation were evaluated, the obtained values were adjusted to the mean using the paired t-test (Microsoft Excel 2000). The disappearance and recovery of the individual reflexes were evaluated using the Fischer test (Sisa Table version).

\section{Results}

Group 1 ( $50 \mu \mathrm{g} / \mathrm{kg}$ of medetomidine) was excluded from statistical processing of pulse rate and respiratory rate and blood oxygen saturation since all rats assigned to the group showed only very weak signs of sedation (reduced interest in food and other animals in the cubicle). Neither the lateral nor the other reflexes monitored disappeared and the animals kept trying to take up a sternal position. Due to motive activity of the animals, the finger probe of the pulse oximeter could not be attached. There was one rat in group $2(100 \mu \mathrm{g} / \mathrm{kg}$ of medetomidine) in whom sedation did not succeed and neither pulse rate nor blood oxygen saturation could be taken.

The average values of respiratory and pulse rate measured in the individual groups of rats are presented in Tables 2 and 3. In all monitored groups respiratory rate and pulse rate decreased gradually. The statistical differences between the times are stated in Tables 2 and 3 . In group 2 statistically significant $(P<0.05)$ decreases in respiratory rate occurred between minute 15 and minute 20 and between minute 55 and minute 60 . In group 3 a statistically significant $(P<0.05)$ decrease in respiratory rate occurred between minute 5 and minute 10 , between minute 10 and minute 15 , and between minute 30 and minute 35 . In group 4 statistically significant $(P<0.05)$ decreases in respiratory rate occurred between minute 15 and minute 20 . In the groups 5 to 7 a statistically significant $(P<0.05)$ decrease in respiratory rate occurred between minute 5 and minute 10 . In group 8 there was no statistically significant difference between subsequently taken respiratory rates. In group 9 a statistically significant $(P<0.05)$ decrease in respiratory rate occurred between minute 50 and minute 55. In group 10 statistically significant $(P<0.05)$ decreases in respiratory rate occurred between minute 20 and minute 25 , between minute 25 and 30 , and between minute 45 and 50 . The drop in respiratory rate in minute 60 compared with minute 5 in groups 2 to 4 was by $30 \%$ at the most. On the other hand, the same drop was by $63 \%$ in group 10 .

The average drop in pulse rate was by $26 \%$ in group 2 , by $18 \%$ in group 3 , and by over $30 \%$ in groups 4 to 10 . The evaluation of blood oxygen saturation showed no significant differences between the groups. The average blood oxygen saturation was $90.9 \pm 4.34 \%$.

From the dosage of $150 \mu \mathrm{g} / \mathrm{kg}$ of medetomidine (group 3) up, the lateral and the palpebral reflexes as well as surface tactile sensibility disappeared in all rats. Group 3 was subjected to a statistical comparison with all remaining groups. The disappearance of the lateral and the palpebral reflex in any of the groups did not differ from group 3 at the level of statistical significance. The differences in the disappearance of surface tactile sensibility and the corneal reflex are presented in Table 4. Depth tactile sensibility remained unimpaired in all animals without exception. The corneal reflex remained unimpaired for quite long including the cases of higher medetomidine dosages (15 minutes after injection of the anaesthetic). After the period, the reflex had disappeared in all rats from groups 5 and 7 to 10, but remained intact in one animal from group $6(300 \mu \mathrm{g} / \mathrm{kg})$ for as long as 25 minutes after injection of the 


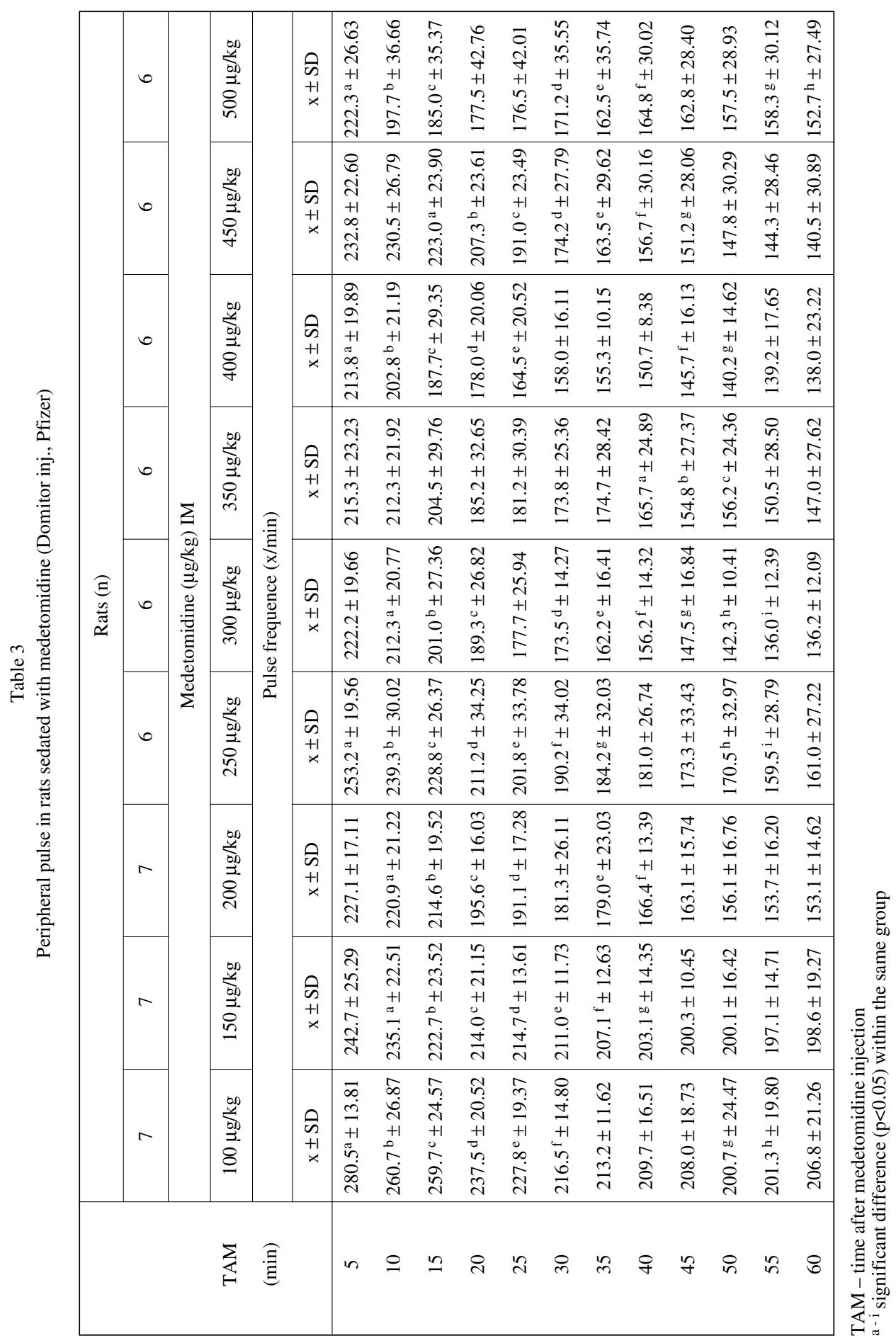




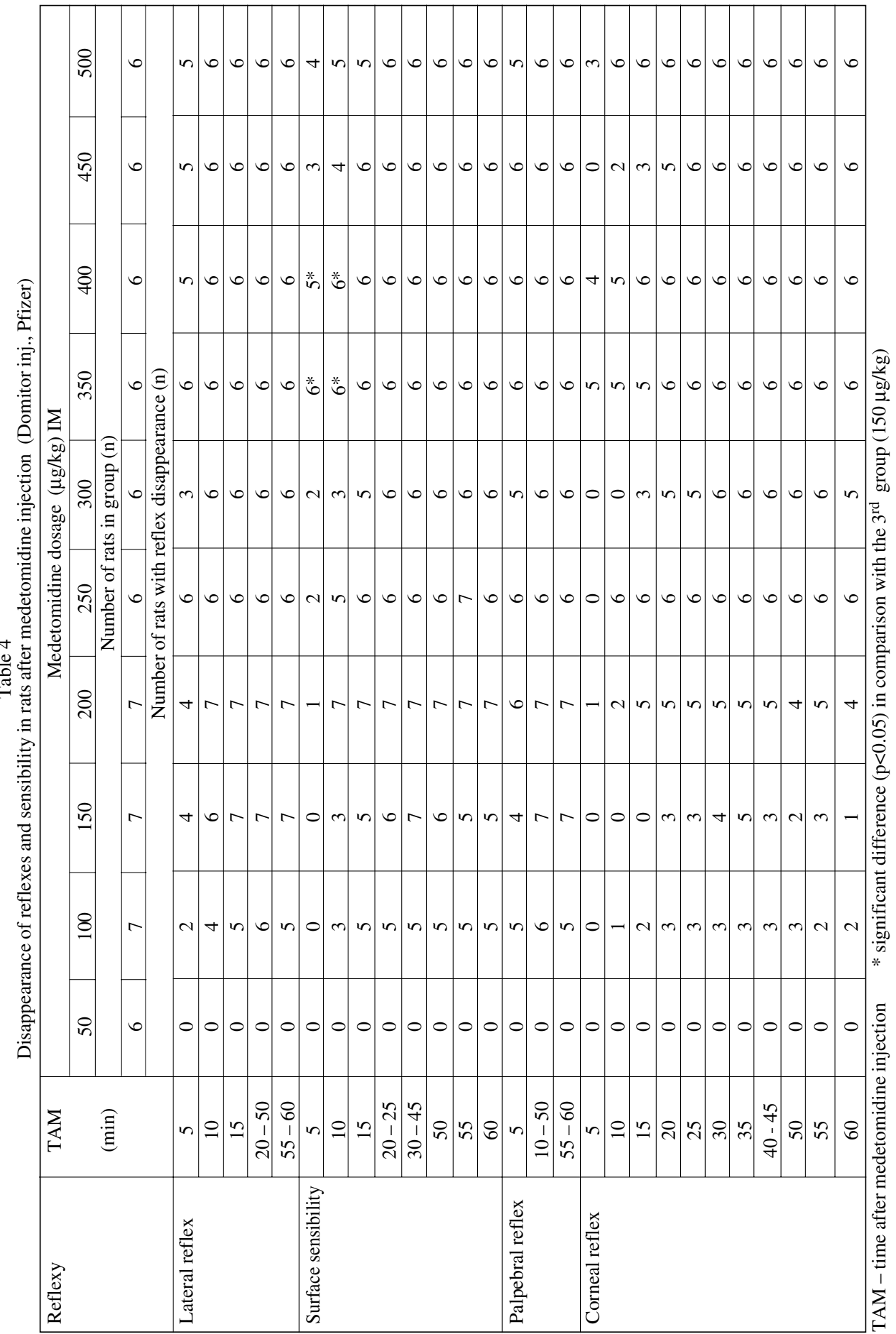


tranquillizer. In group 3 a significant $(P<0.05)$ difference in disappearance of the corneal reflex occurred between minute 15 and minute 20. In group 4 a significant $(P<0.05)$ difference in disappearance of the corneal reflex occurred between minute 10 and minute 15. In group 5 a significant $(P<0.05)$ difference in disappearance of the corneal reflex occurred between minute 10 and minute 15. In group 6 significant $(P<0.05)$ differences in disappearance of the corneal reflex occurred between minute 5 and minute 10 and between minute 10 and minute 15 . In group 5 a significant $(P<0.05)$ difference in disappearance of the corneal reflex occurred between minute 5 and minute 10 . In group 3 a significant $(P<$ 0.05 ) difference in disappearance of the corneal reflex occurred between minute 10 and minute 15 .

The recovery of the monitored reflexes after the atipamezole injection was within 3 minutes in group 2, within 2 minutes in groups 3 and 4, within 3 minutes in group 5, within 5 minutes in group 6, within 4 minutes in group 7, within 2 minutes in group 8, within 4 minutes in group 9, and within 3 minutes in group 10 (see Table 5).

\section{Discussion}

We do not regard the palpebral or the corneal reflex as suitable for evaluating sedation due to the lack of reliability of their evaluation. Moreover, evaluating the loss of the corneal reflex by palpation may result in corneal damage (S mith 1993). There are authors who do not evaluate the corneal and the palpebral reflex at all ( $\mathrm{Hu}$ et al. 1992). It was evaluation of the lateral reflex and of surface and depth tactile sensibility that we regarded as suitable for this purpose. We defined the onset of sedation as the moment of loss of the lateral reflex. In our population of rats the dosage of $50 \mu \mathrm{g} / \mathrm{kg}$ of medetomidine did was not sufficient for achieving good-quality sedation. In contrast to cats and dogs, small mammals require higher dosages of medetomidine (Thurmon et al. 1996; Mason 1997; Muir et al. 1999). The medetomidine dosages recommended for rats by Jon son-Delaney (1999) range between 150 and $250 \mu \mathrm{g} / \mathrm{kg}$. Increasing the dosages further did not improve the quality of sedation while evoking a relatively strong respiratory depression.

A drop in the pulse rate was recorded in rats of all the monitored groups. This result is in accordance with the effects of medetomidine on the cardiovascular system of dogs and cats (Lukasik 1999; Muir and Mason 1996) as well as of wild animals (Jalanka et al. 1990). Not even the highest dosage of $500 \mu \mathrm{g} / \mathrm{kg}$ of medetomidine did, however, cause a decrease in blood oxygen saturation in the monitored population.

Lukasik (1999) writes of recovery of reflexes after atipamezole injection within 5 to 10 minutes. In out trial, the reflexes in rats had recovered within 5 minutes.

\section{Využití medetomidinu pro sedaci u laboratorního potkana Rattus norvegicus}

U 63 potkanů (Rattus norvegicus), rozdělených po 6-7 do deseti skupin jsme hodnotili hloubku a kvalitu sedace navozené intramuskulární aplikací medetomidinu. V první skupině byl medetomidin aplikován v dávce $50 \mu \mathrm{g} / \mathrm{kg}$, v dalších skupinách $100 \mu \mathrm{g} / \mathrm{kg}, 150$ $\mu \mathrm{g} / \mathrm{kg}, 200 \mu \mathrm{g} / \mathrm{kg}, 250 \mu \mathrm{g} / \mathrm{kg}, 300 \mu \mathrm{g} / \mathrm{kg}, 350 \mu \mathrm{g} / \mathrm{kg}, 400 \mu \mathrm{g} / \mathrm{kg}, 450 \mu \mathrm{g} / \mathrm{kg}$ a $500 \mu \mathrm{g} / \mathrm{kg}$. Dechová frekvence, periferní puls, saturace krve kyslíkem, ztráta a opětovný návrat reflexủ byly vyhodnocovány po dobu 60 minut od okamžiku aplikace medetomidinu v pětiminutových intervalech. Ke ztrátě laterálního reflexu došlo u 3. skupiny do 15 minut u 4.- 10. skupiny do 10 minut. Za vrchol sedace považujeme u sledovaného souboru potkanů interval mezi 10. a 20. minutou. U všech skupin došlo k poklesu pulsové frekvence. U 2. skupiny se snížila v průměru o $26 \%$, u 3 . skupiny o $18 \%$, u 4. - 10. skupiny o více než 30 $\%$. U skupin 2. až 4. došlo ke snížení dechové frekvence v 60. minutě oproti 5 . minutě maximálně o $30 \%$. U 10. skupiny došlo ke snížení o $63 \%$. Při statistickém hodnocení saturace krve kyslíkem jsme nezjistili žádné statisticky významné rozdíly mezi jednotlivými 


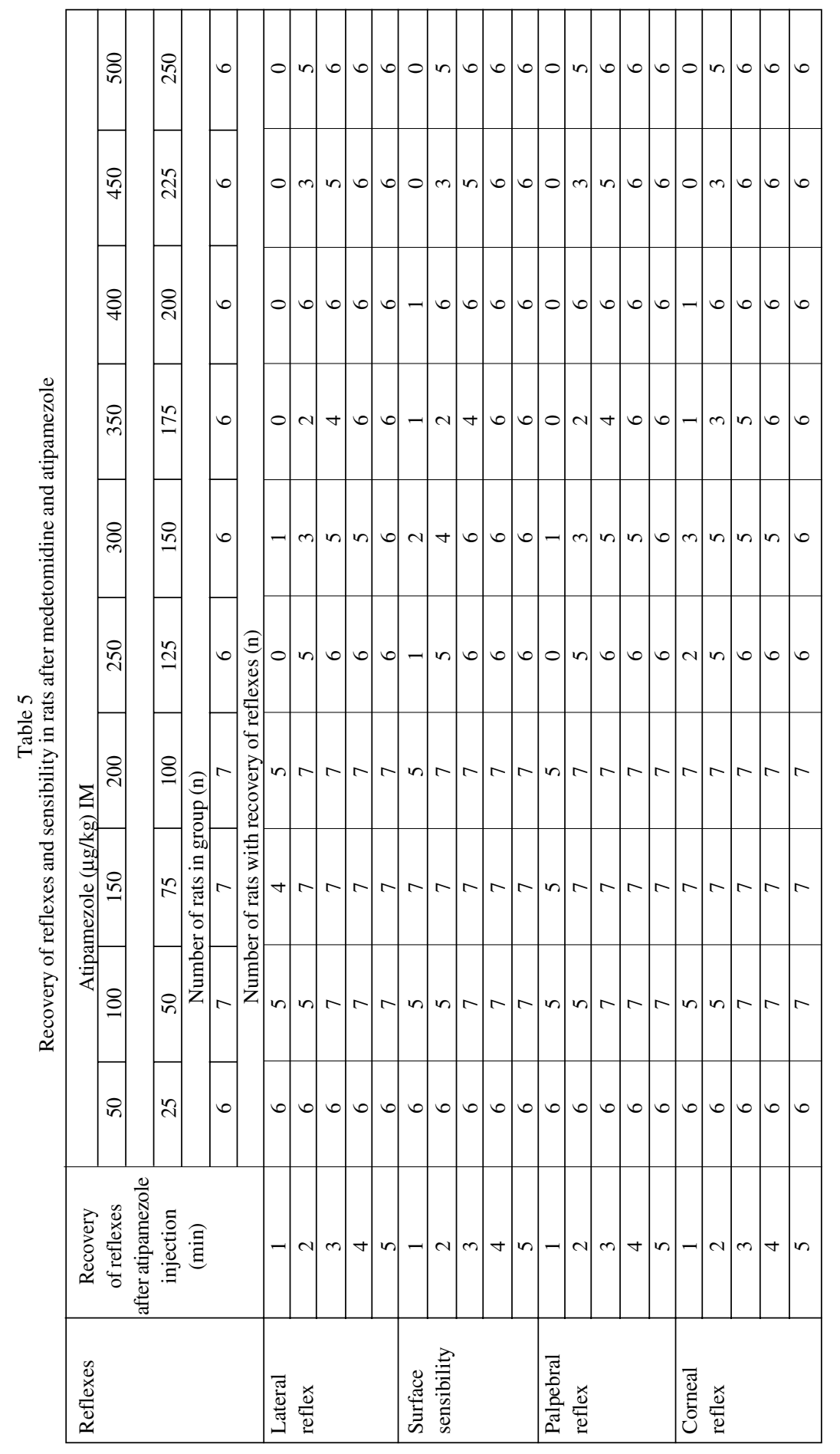


skupinami. Průměrná saturace krve kyslíkem byla $90.9 \pm 4.34 \%$. Opětovný návrat reflexů po aplikaci atipamezolu byl kontrolován v minutových intervalech. K návratu všech hodnocených reflexů došlo do 5 minut. K sedaci potkanů doporučujeme dávky medetomidinu v rozmezí $150-250 \mu \mathrm{g} / \mathrm{kg}$. Vyšší dávky způsobují poměrně silnou depresi dýchání.

\section{Acknowledgements}

We thank to dr. M. Vyskočil and dr. K. Hauptmanová for their assistance with the statistical treatment of the results and to dr. P. Raušer for his comments and proposals regarding the methodology of the trial. The study received partial support from the grant of the Internal Grant Agency of the University of Veterinary and Pharmaceutical Sciences, Brno (IGA 28/2002/FVL) and the grant of the Ministry of Education, Youth, and Sports (Research Project No. 161700002).

\section{References}

BRAMMER, DW, DOERING, BJ, CHRISP, CE, RUSH, HG 1991: Anesthetic and nefrotoxic effect of Telazol in New Zealand white rabbits. Lab Anim Sci 41: 432-435

CANTWELL, SL 2001: Ferret, rabbit, and rodent anesthesia. Veter Clin North Amer Exotic Anim Pract 4: 169 191

CLARKE, KW 1992: Premedication and sedation. In: HILBERRY, ADR (Ed.): Manual of Anaesthesia for Small Animal Practice. $3^{\text {rd }}$ ed., BSAVA, Cheltenham, pp. 39-49

DOERING, BJ, BRAMMER, DW, CHRISP, CE, RUSH, HG 1992: Nephrotoxicity of tiletamine in New Zealand white rabbits. Lab Anim Sci 42: 267-269

FLECKNELL, P 1991: Anaesthesia and postoperative care of small practice. In Practice 9: 180-189

FLECKNELL, PA, LILES, JH 1996: Halotane anaesthesia in the rabbit: A comparison of the effects of medetomidine, acepromazine, and midazolam on breath-holding during induction. J Ass Veter Anaest 23: 1114

HESS, L, DVOŘÁČEK, I, SVOBODNÍK, J 1984: Hlodavci. In: HESS L., DVOŘÁČEK I., SVOBODNÍK, J (Ed.): Anestezie laboratorních zvířat, Avicenum, Praha, pp. 158-189

HU, C, FLECKNELL, PA, LILES, JH 1992: Fentanyl and medetomidine anaesthesia in the rat and its reversal using atipamezole and either nalbuphine or butorphanol. Lab Anim 26: 15-22

JALANKA, HH 1989: Medetomidine and ketamine-induced immobilization of snow leopards (Panthera uncia): Doses, evaluation, and reversal by atipamezole. J Zoo Wildlife Med 20: 154-162

JALANKA, HH, BENGT, O, ROEKEN, BO 1990: The use of medetomidine, medetomidine - ketamine combinations, and atipamezole in non-domestic mammals: A review. J Zoo Wildlife Med 21: 259-282

JONSON-DELANEY, C 1999: Medetomidine in small mammals. Exotic DVM 5: 35-36

KLEIN, LV, KLIDE, AM 1989: Central alfa2-adrenergic and benzodiazepine agonists and their antagonists. J Zoo Wildlife Med 20: 138-153

KO, JCH, MCGRATH, CJ, NICKLIN, CF 1997: Answers to your questions about medetomidine and atipamezole. Vet Med 92: 415-425

LANGAN, JN, SCHUMAKER, J, POLLOCK, C, OROSZ, SE, JONES, MP, HARVEY, RC 2000 Cardiopulmonary and anesthetic effect of medetomidine-ketamine-butorphanol and antagonism with atipamezole in servals (Felis serval). J Zoo Wildlife Med 34: 329-334

LUKASIK, VM 1999: Premedication and sedation. In: SEYMOUR, C, GLEED, R (Ed.): Manual of Small Animal Anaesthesia and Analgesia. BSAVA, Cheltenham, pp. 71-85

MASON, DE 1997: Anesthesia, analgesia, and sedation for small mammals. In: HILLYER, E V, QUESENBERRY, KE (Ed.): Ferrets, Rabbits, and Rodents Clinical Medicine and Surgery. W. B. Saunders Comp., Philadelphia, pp. 378-391

MUIR, WW, FORD, JL, KARPA, GE, HARRISON, EE, GADAWSKI, JE 1999: Effect of intramuscular administration of low doses of medetomidine and medetomidine-butorphanol in middle-aged and old dogs. JAVMA, 215: 1116-1120

MUIR, WW, MASON, D 1996: Cardiovascular system. In: THURMON, JC, TRANQUILLI, WJ, BENSON, GJ (Ed.): Lumb and Jones' Veterinary Anesthesia, $3^{\text {rd }}$ ed., Williams and Wilkins, Baltimore, pp. 62-114

SMITH, W 1993: Responses of laboratory animals to some injectable anaesthetics. Lab Anim 27: 30-39

THURMON, JC, TRANQUILLI, WJ, BENSON, GJ 1996: Preanesthetics and anesthetic adjuncts. In: THURMON, JC, TRANQUILLI, WJ, BENSON, GJ (Ed).: Lumb and Jones' Veterinary Anesthesia. $3^{\text {rd }}$ edition, Williams and Wilkins, Baltimore, pp. 183-209 